\title{
Sistem Informasi Rumah Sakit Umum Daerah Kota Padang Panjang Berbasis Php dan Database MySql
}

\author{
Fadillah Akbar, Aulia Fitrul Hadi \\ Universitas Putra Indonesia "YPTK" Padang \\ E-mail: $\underline{\text { akbarfadillah805@gmail.com }}$
}

\begin{abstract}
Abstrak
Saat ini komputer hampir dapat dijumpai di setiap kantor, perusahaan, sekolah, atau bahkan rumah tangga. Perkembangan teknologi komputer yang sangat pesat, khususnya dibidang perangkat lunak, membuat komputer menjadi semakin user friendly dan telah menjadikannya suatu kebutuhan bagi kalangan tertentu, misalnya kalangan bisnis. Komputer tidak lagi hanya digunakan sebagai pengganti mesintik ataupun alat hitung, namun kini juga banyak digunakan dalam membantu pembuatan keputusan penting. Akibatnya, informasi yang disimpan memerlukan pengamanan yang dapat melindungi terhadap akses orang yang tidak atau berhak. Dan dengan adanya perkembangan teknologi ini maka pada penelitian ini telah dikembangkan sebuah system untuk pelayanan kesehatan yang ada di Rumah Sakit Umum Daerah Kota Padang Panjang. Metode yang digunakan untuk aplikasi ini adalah Data Flow Diagram dan Entity Relationship Diagram. Dan untuk bahasa pemrogramannya menggunakan PHP sedangkan untuk basisdatanya menggunakan $M y S Q L$. Sistem informasi yang dibangun ini mampu memberikan kemudahan informasi untuk admin, perawat, dan direktur untuk melakukan tugasnya. Membantu admin, perawat, dan direktur untuk mencari informasi yang berkaitan dengan pelayanan kesehatan masyarakat. Sistem informasi ini memberikan informasi tentang pelayanan yang diselenggarakan oleh para bagian petugas rumah sakit. Dalam memberikan pelayanan kepada masyarakat.
\end{abstract}

Kata kunci: Sistem Informasi, PHP, MySQL, Rumah Sakit.

\begin{abstract}
Nowadays computers can almost be found in every office, company, school, or even household. The development of computer technology is very rapid, especially in the field of software, making computers become more user friendly and has made it a necessity for certain circles, for example businesses. Computers are no longer only used as a substitute for messpot or arithmetic, but are now also widely used in helping important decision making. As a result, the information stored requires security that can protect against unauthorized access. And with the development of this technology, this research has developed a system for health services in the Padang Panjang City General Hospital. The methods used for this application are Data Flow Diagrams and Entity Relationship Diagrams. And for the programming language using PHP while for the database using MySQL. The information system that was built was able to provide information convenience for admins, nurses, and directors to do their jobs. Helping administrators, nurses, and directors to find information related to public health services. This information system provides information about services provided by the hospital staff. In providing services to the community.
\end{abstract}

Keywords: Information System, PHP, MySQL, Hospital.

\section{Latar Belakang}

Sistem Informasi saat ini telah berkembang dengan pesat dan juga kebutuhan akan sistem informasi itu sendiri semakin tinggi setiap tahunnya. Sistem informasi dapat diaplikasikan diberbagai kegiatan usaha, 
mulai dari perusahaan jasa, dagang, manufaktur dan lainnya. Sistem Informasi merupakan interaksi antara data, manusia dan prosedur yang didukung oleh hardware dan software, yang berguna untuk memberikan suatu penyelesaian berupa informasi yang dapat dipakai untuk mengambil suatu keputusan baik berupa jangka pendek, menengah atau panjang dalam sebuah organisasi atau perusahaan. Dengan kata lain sistem informasi adalah suatu kumpulan dari komponen-komponen yang saling berinteraksi untuk mengelola informasi pada suatu organisasi atau perusahaan untuk mendukung kegiatan organisasi atau perusahaan lainnya. Dalam observasi ini, penulis mengamati dan mengambil objek penelitian mengenai penerapan sistem informasi pada Rumah Sakit Umum Daerah Kota Padang Panjang. Adapun permasalahan yang dibahas pada Rumah Sakit Umum Daerah Kota Padang Panjang berfokus dibidang Rekam Medis, Rawat Inap, Rawat Jalan. dimana data tersebut meliputi data tindakan medis, data pasien, data pendaftaran pasien, data rawat jalan, data rawat inap, adapun tambahannya adalah data obat dan data ruang. Karena sistem yang digunakan pihak rumah sakit belum efektif dalam mengolah data rekam medis rawat inap dan rawat jalan apalagi pekerjaanya menyangkut dengan hasil rekam medis pasien. hal itu masih tergolong manual jika dilihat pada perkembangan teknologi saat ini. Untuk mengatasi hal tersebut penulis membutuhkan suatu sistem yang dapat membantu proses pengerjaan secara cepat, tepat dan akurat. Dan dapat menghasilkan laporan rekam medis, rawat inap dan rawat jalan sebagai mana di atas secara rinci.

\section{Metodologi}

Adapun metode penelitian yang dilakukan seperti berikut :

a Penelitian Lapangan

Pada penelitian lapangan ini dilakukan wawancara dengan staff rumah sakit terkait dengan rekam medis, rawat jalan dan rawat inap, untuk menganalisis masalah, serta memperoleh informasi yang dibutuhkan. Melakukan kegiatan pengamatan yang berhubungan dengan objek penelitian secara langsung kelokasi penelitian, seperti dilakukannya data, pengamatan objek penelitian, dan lain-lain.

\section{b Riset Perpustakaan}

Riset perpustakaan ini dilakukan dengan cara membaca, membahas, meringkas, dan membuat kesimpulan dari buku-buku, teori pada perpustakaan, dan jurnal-jurnal yang ada kaitannya dengan penelitian.

\section{c Penelitian Laboratorium}

Pada tahap ini melakukan perancangan pengelolaan data yang berhubungan dengan data rumah sakit untuk menghasilkan informasi yang valid. Dalam hal ini penelitian dilakukan dengan merancang program atau perangkat lunak yang sesui dengan topik dan permasalahan yang dihadapi dan juga dalam hal penyusunan laporan secara keseluruhan.

\section{Hasil dan Diskusi}

Pengujian sistem dilakukan untuk mengetahui sejauh mana sistem informasi yang dirancang dapat mengatasi masalah, serta untuk mengetahui hubungan antar komponen sistem. 


\section{Copyright@2020 LPPM UPI YPTK}

\subsection{Login}

Setelah melakukan tahap penginstalan XAMPP dan pembuatan database rsud_database, kemudian buka Sistem Informasi RSUD Padang Panjang dan pilih Sign In, sehingga tampil form login, kemudian isi username, dan password seperti Gambar 5.1 :

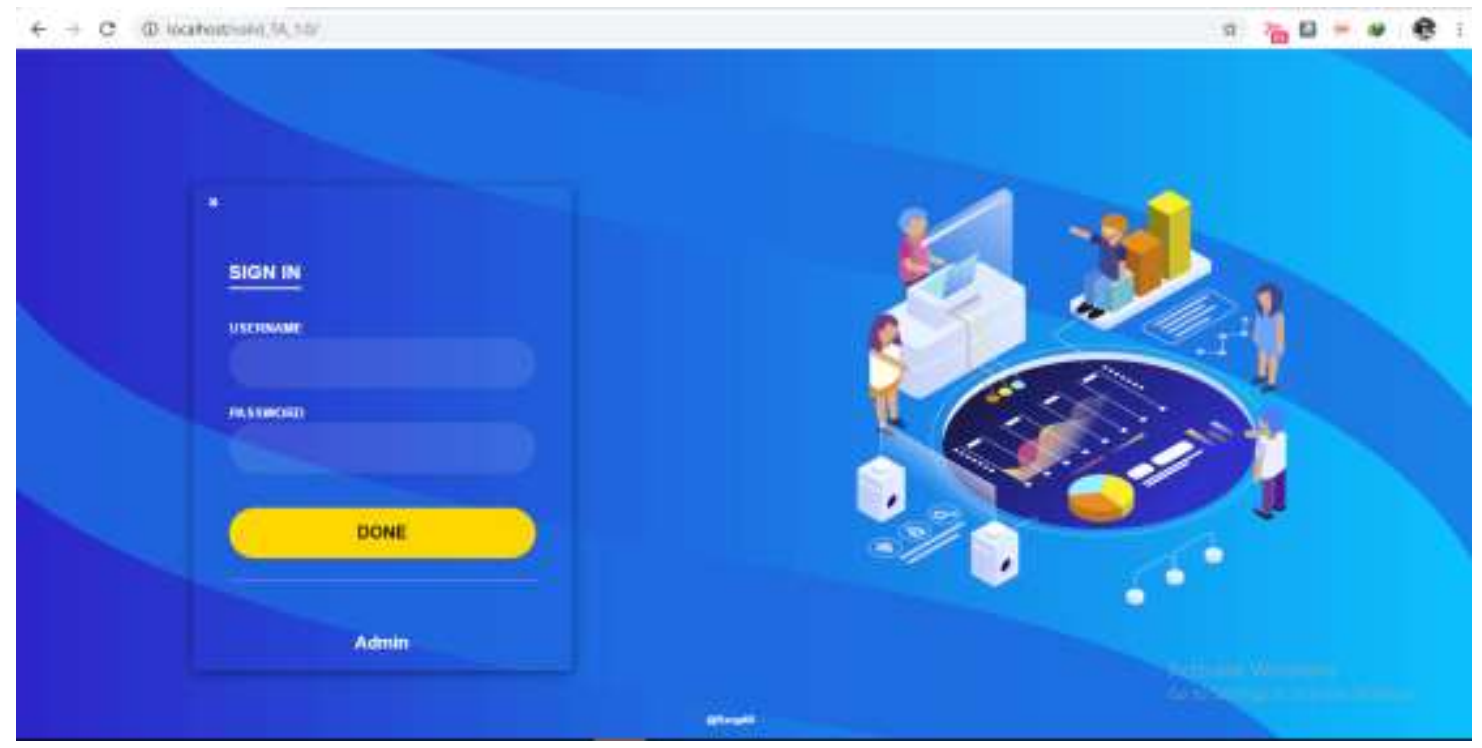

Gambar 5.1 Tampilan Login Admin

Pada saat bagian admin melakukan login dan masuk ke dalam sistem, tampilan yang tersedia terdiri dari menu entry data pasien, entry data ruang, entry data obat, kelola user, menu lihat data, laporan, dan juga logout.

Pada saat bagian perawat melakukan login dan masuk ke dalam sistem, tampilan yang tersedia terdiri dari menu dashboard(tabel pasien), kelola data rekammedis, kelola data rawat inap, kelola data rawat jalan, menu lihat data, dan juga logout.

Pada saat bagian direktur melakukan login dan masuk ke dalam sistem, tampilan yang tersedia terdiri dari menu lihat data, laporan, dan juga logout.

\subsection{Menu yang tersedia}

Tampilan ini merupakan menu-menu yang terdapat di dalam Sistem Informasi RSUD Padang Panjang. Tampilan ini dapat digunakan oleh admin, perawat dan direktur. Menu ini akan muncul berdasarkan pilihan level login masing-masing pengguna. sebagai berikut :

\section{Menu Admin}

Menu Admin merupakan menu-menu yang bisa diakses oleh admin setelah berhasil melakukan login, seperti pada Gambar 5.2: 


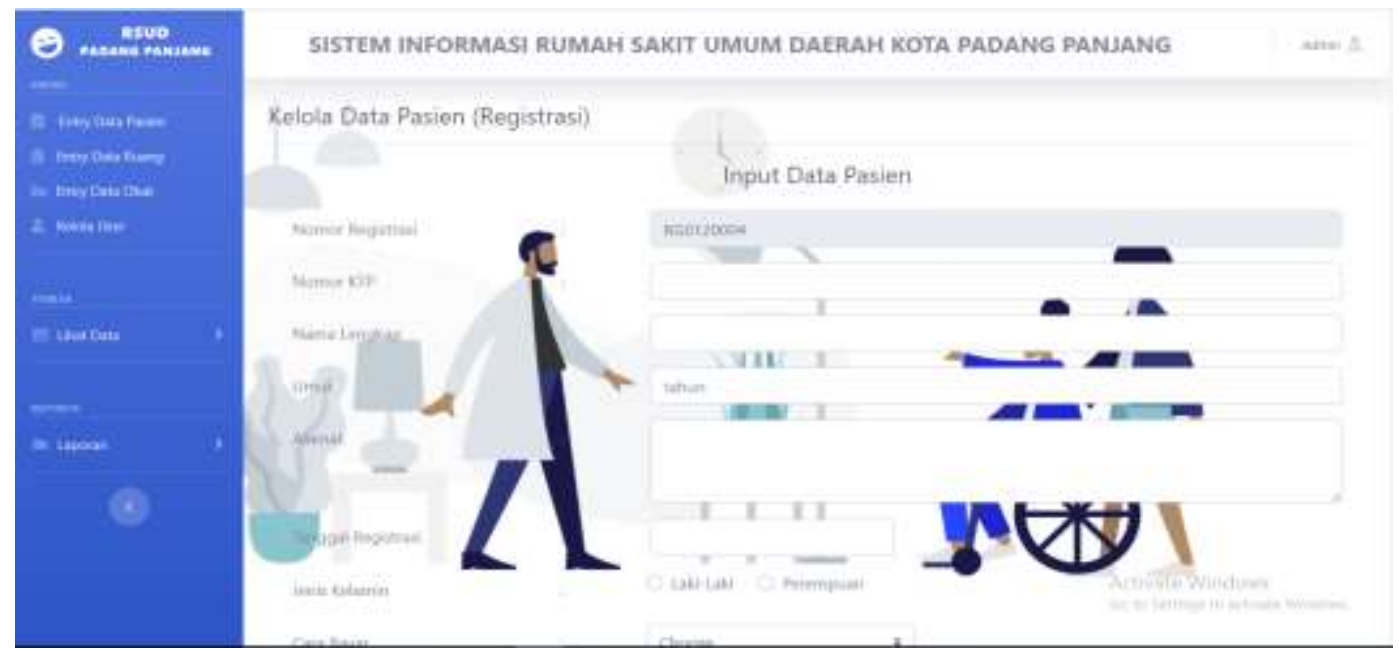

\section{Gambar 5.2 Tampilan Menu Admin}

\section{Menu Perawat}

Menu Perawat merupakan menu-menu yang bisa diakses oleh perawat setelah berhasil melakukan login, seperti pada Gambar 5.3.

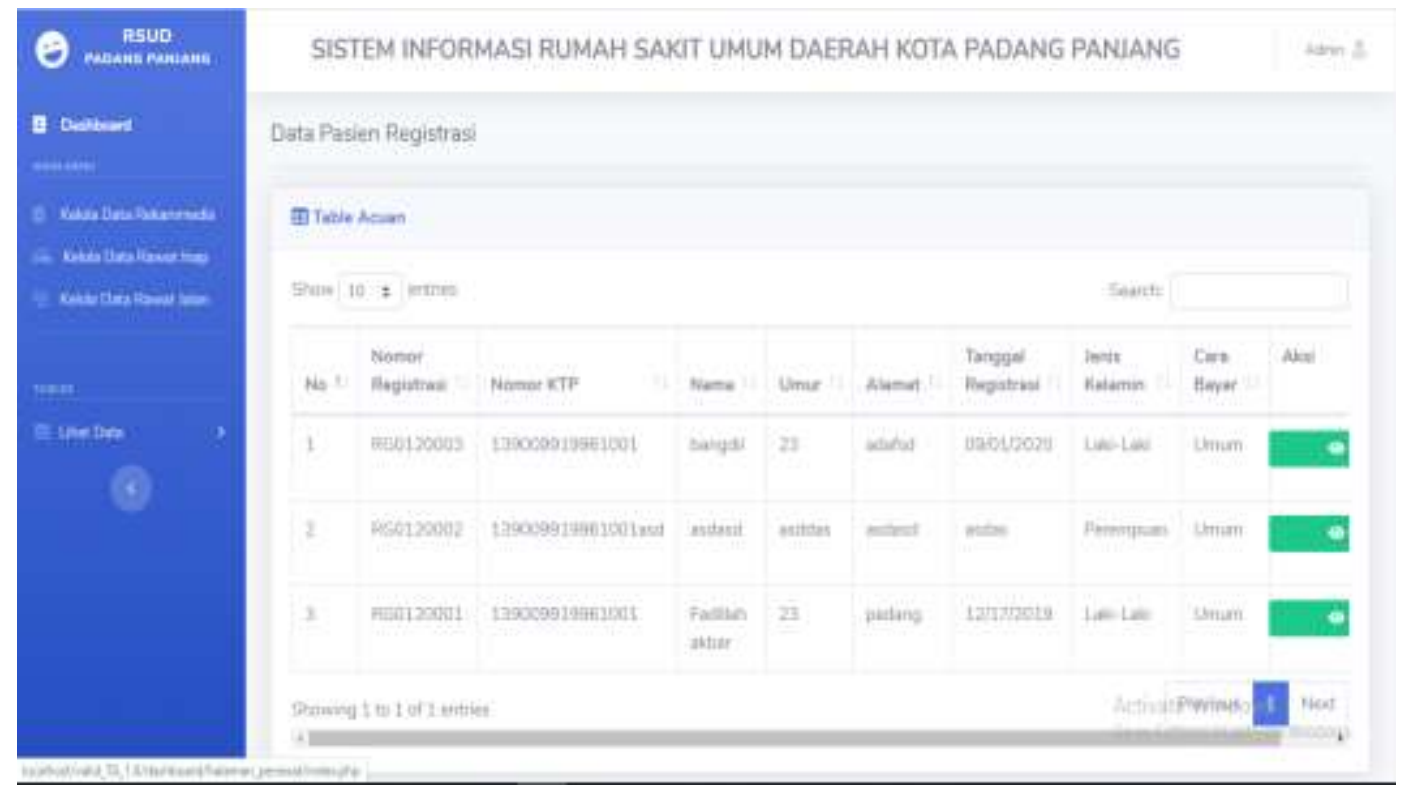

\section{Gambar 5.3 Tampilan Menu Perawat}

\section{Menu Direktur}

Menu Direktur merupakan menu-menu yang bisa diakses oleh direktur setelah berhasil melakukan login, seperti pada Gambar 5.4. 


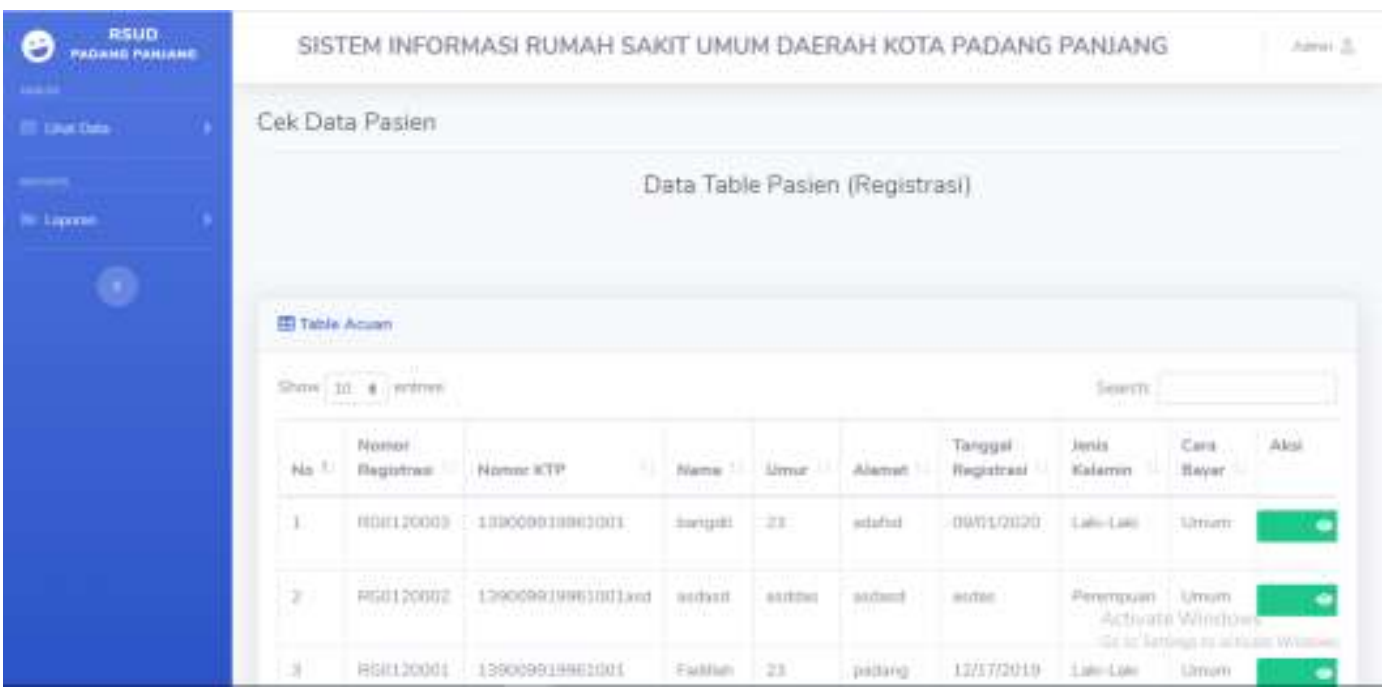

Gambar 5.4 Tampilan Menu Direktur

\section{Sub Menu Entry Data Ruang Admin}

Sub menu ini merupakan menu input data ruang untuk menginputkan data ruang oleh admin kedalam database, seperti pada Gambar 5.5.

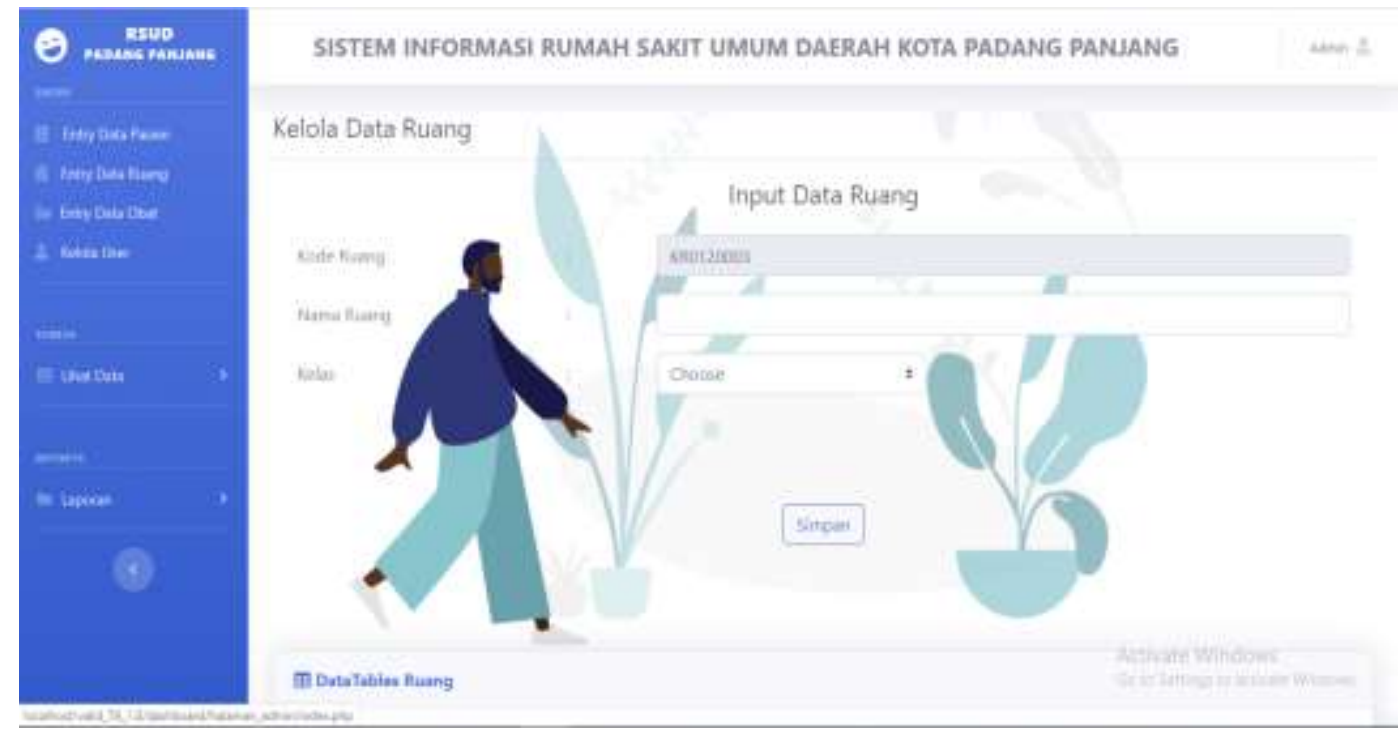

Gambar 5.5 Tampilan Sub Menu Entry Data Ruang Admin

\section{Sub Menu Entry Data Obat Admin}

Sub menu ini merupakan menu input data obat untuk menginputkan data obat oleh admin kedalam database, seperti pada Gambar 5.6. 

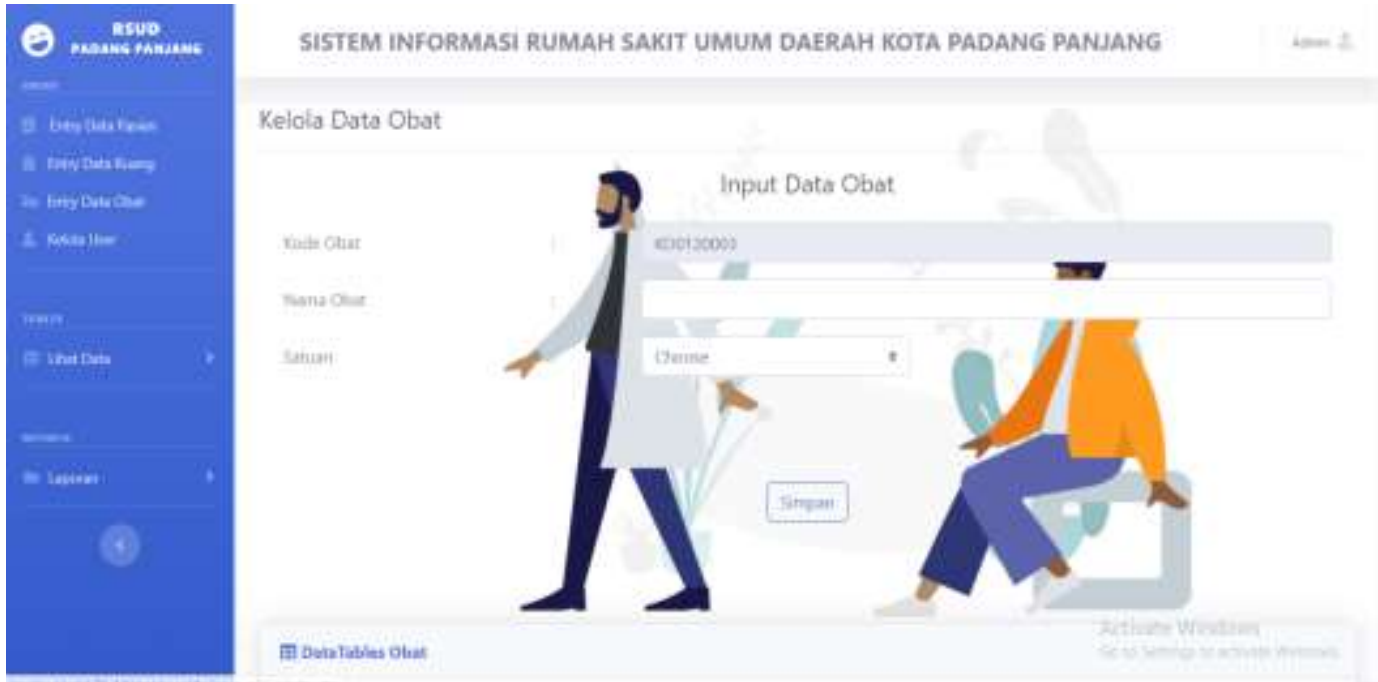

Gambar 5.6 Tampilan Sub Menu Entry Data Obat Admin

\section{Sub Menu Kelola User Admin}

Sub Menu ini merupakan menu input data user untuk menambah user dan memberikan hak akses kepada user, seperti pada Gambar 5.7.
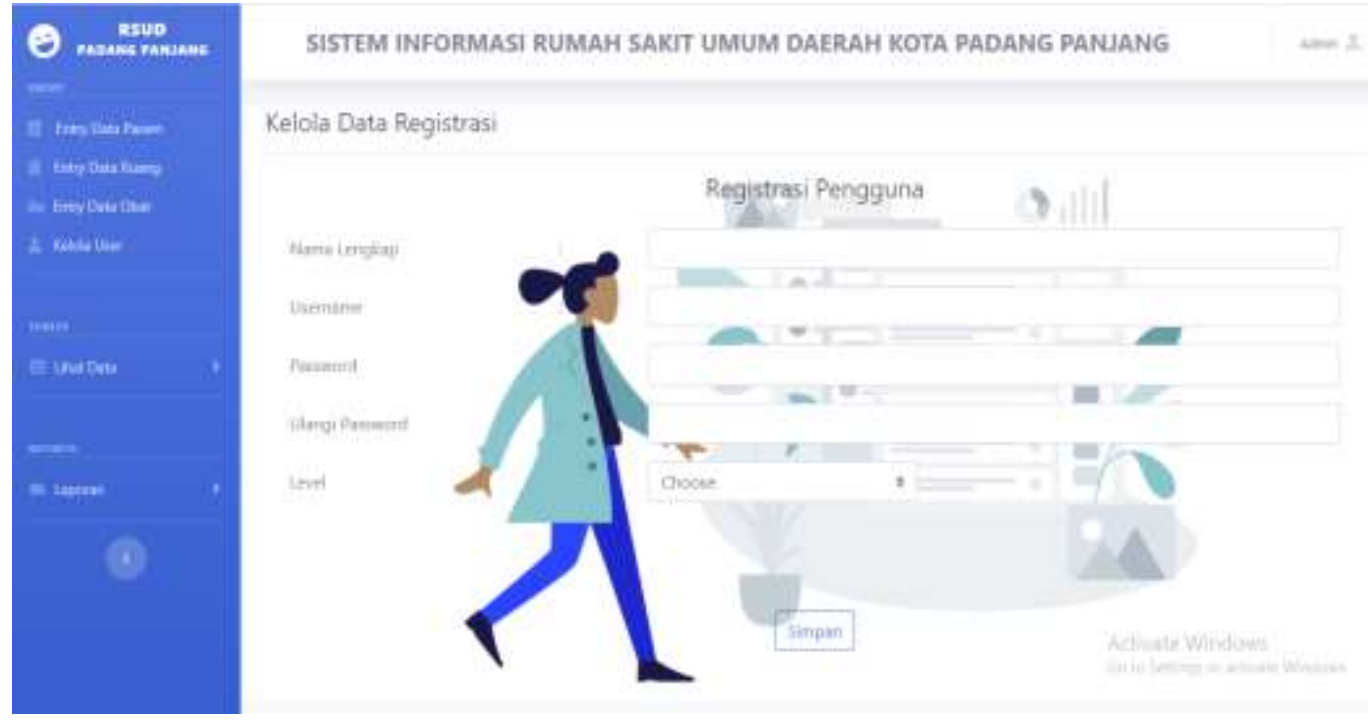

Gambar 5.7 Tampilan Sub Menu Kelola User Admin

\section{Sub Menu Lihat Data Pasien Admin}

Sub Menu lihat data pasien ini merupakan menu yang digunakan oleh admin untuk melihat data yang sudah diinputkan, seperti Gambar 5.8. 


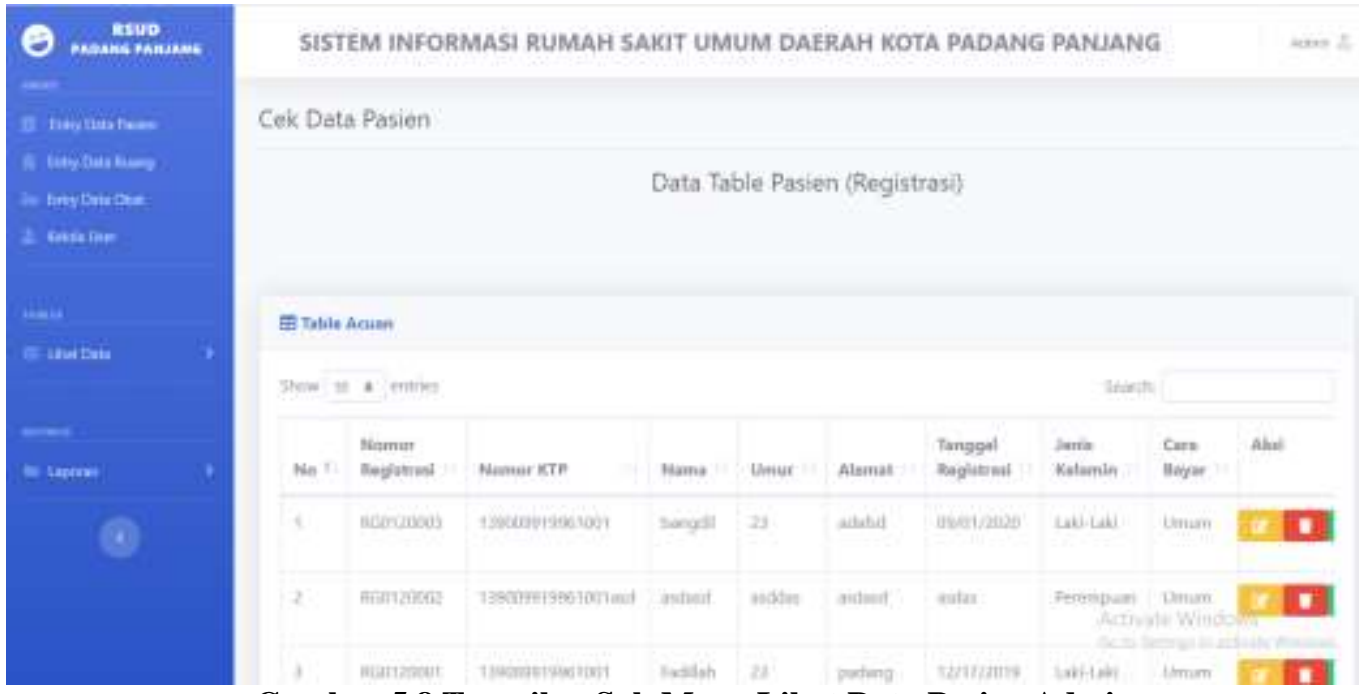

Gambar 5.8 Tampilan Sub Menu Lihat Data Pasien Admin

\section{Sub Menu Lihat Data Rekammedis Admin}

Sub Menu lihat data rekammedis ini merupakan menu yang digunakan oleh admin untuk melihat data yang sudah diinputkan oleh perawat seperti Gambar 5.9.

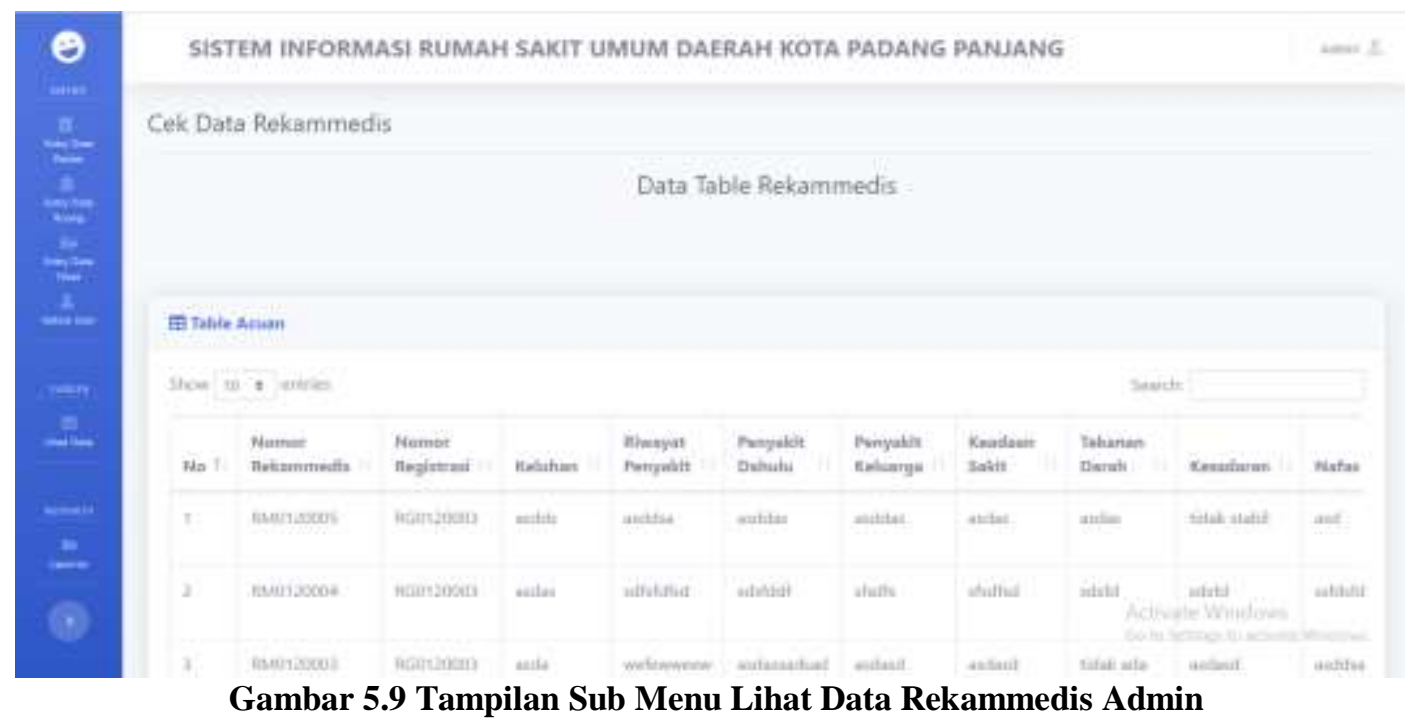

\section{Sub Menu Lihat Data Rawat Inap Admin}

Sub Menu lihat data rawat inap ini merupakan menu yang digunakan oleh admin untuk melihat data yang sudah diinputkan oleh perawat seperti Gambar 5.10. 


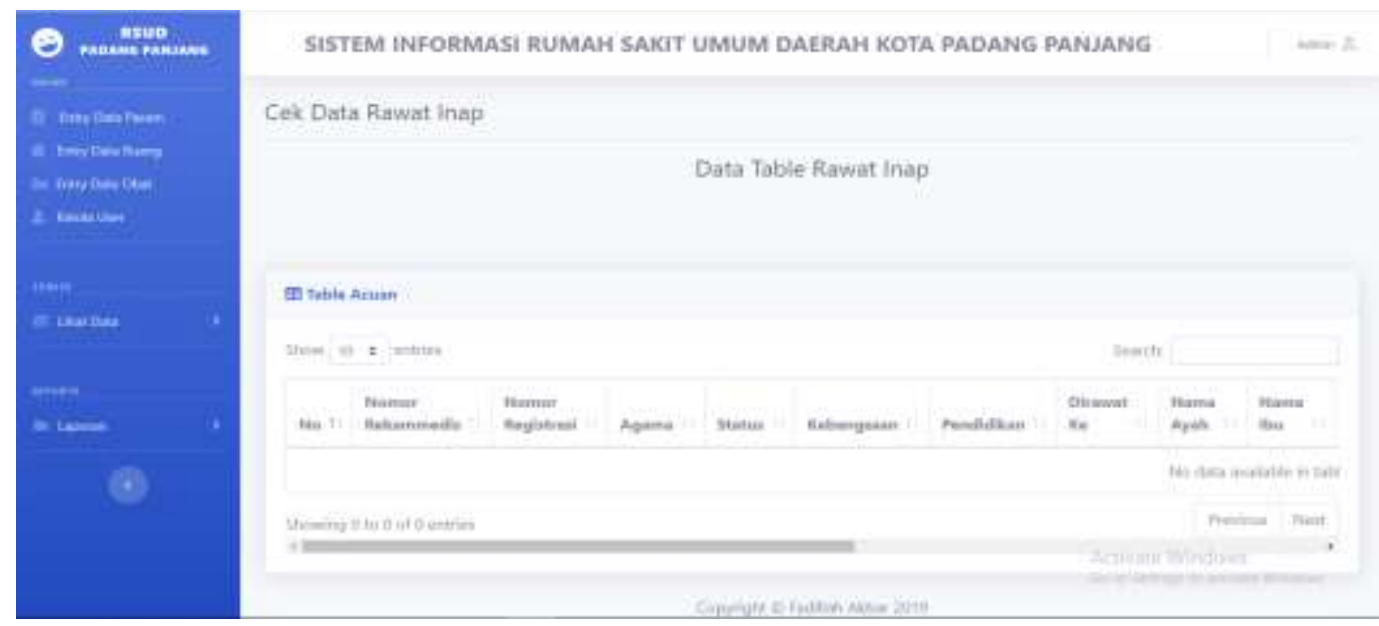

Gambar 5.10 Tampilan Sub Menu Lihat Data Rawat Inap Admin

\section{Sub Menu Lihat Data Rawat Jalan Admin}

Sub Menu lihat data rawat inap ini merupakan menu yang digunakan oleh admin untuk melihat data yang sudah diinputkan oleh perawat seperti Gambar 5.11.

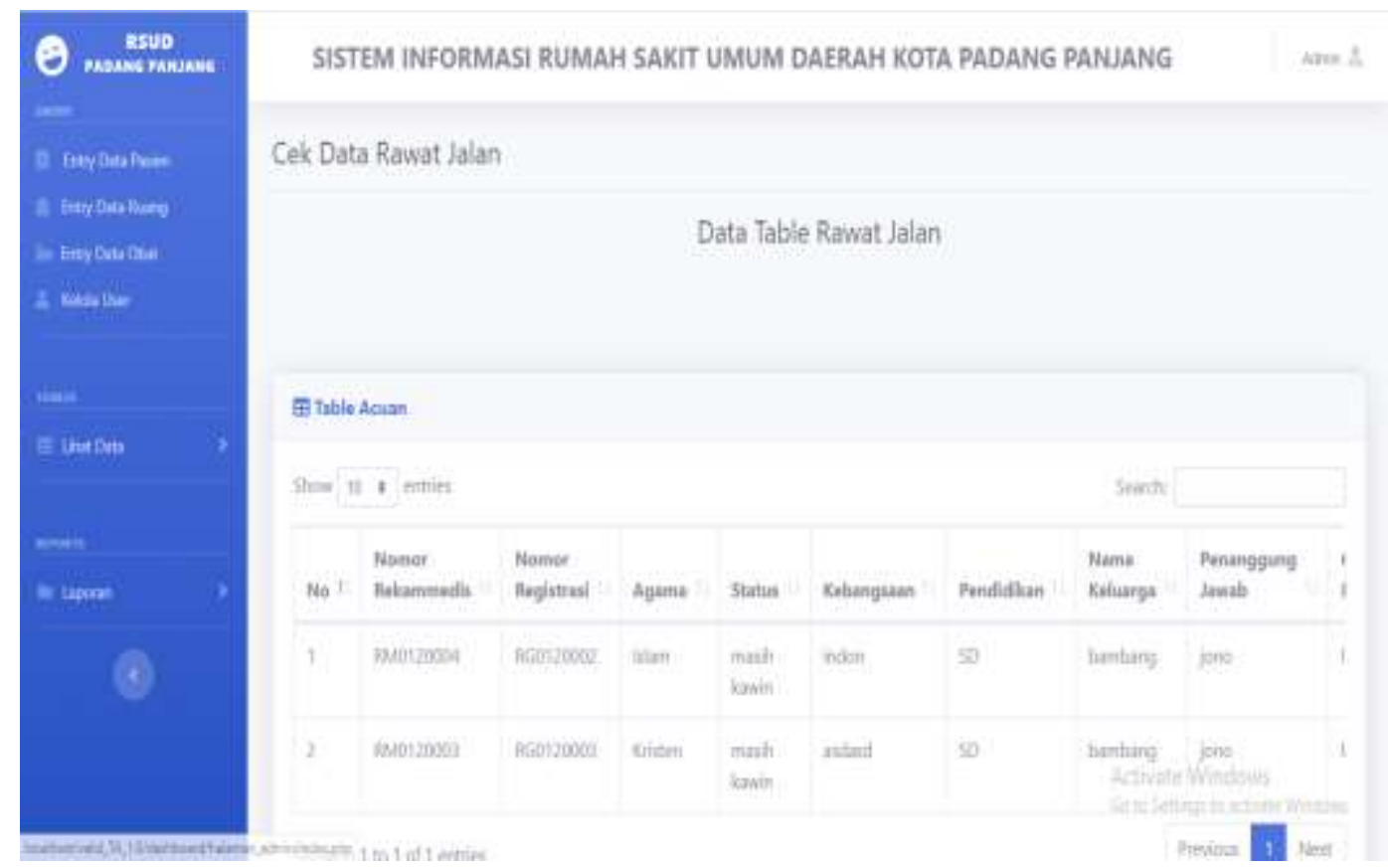

Gambar 5.11 Tampilan Sub Menu Lihat Data Rawat Jalan Admin

\section{Sub Menu Laporan Rekammedis pada Admin}

Sub menu laporan data rekammedis merupakan sub menu yang digunakan untuk mengelola dan mencetak laporan data rekammedis seperti Gambar 5.12 


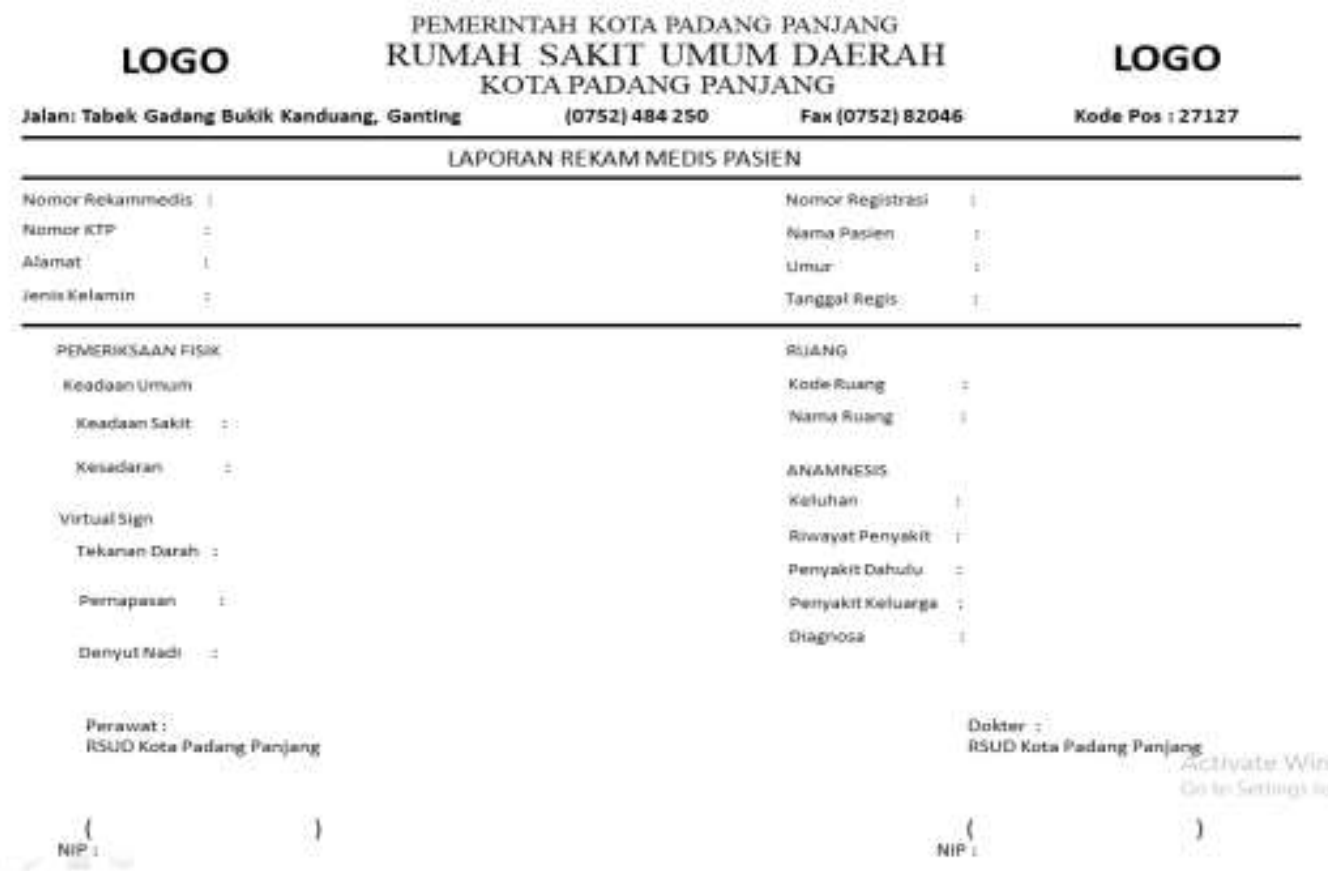

Gambar 5.12 Tampilan Sub Menu Laporan Data Rekammedis

\section{Sub Menu Laporan Rawat Inap pada Admin}

Sub menu laporan data rawat inap data pasien merupakan sub menu yang digunakan untuk mengelola dan mencetak laporan data rawat inap seperti Gambar 5.13

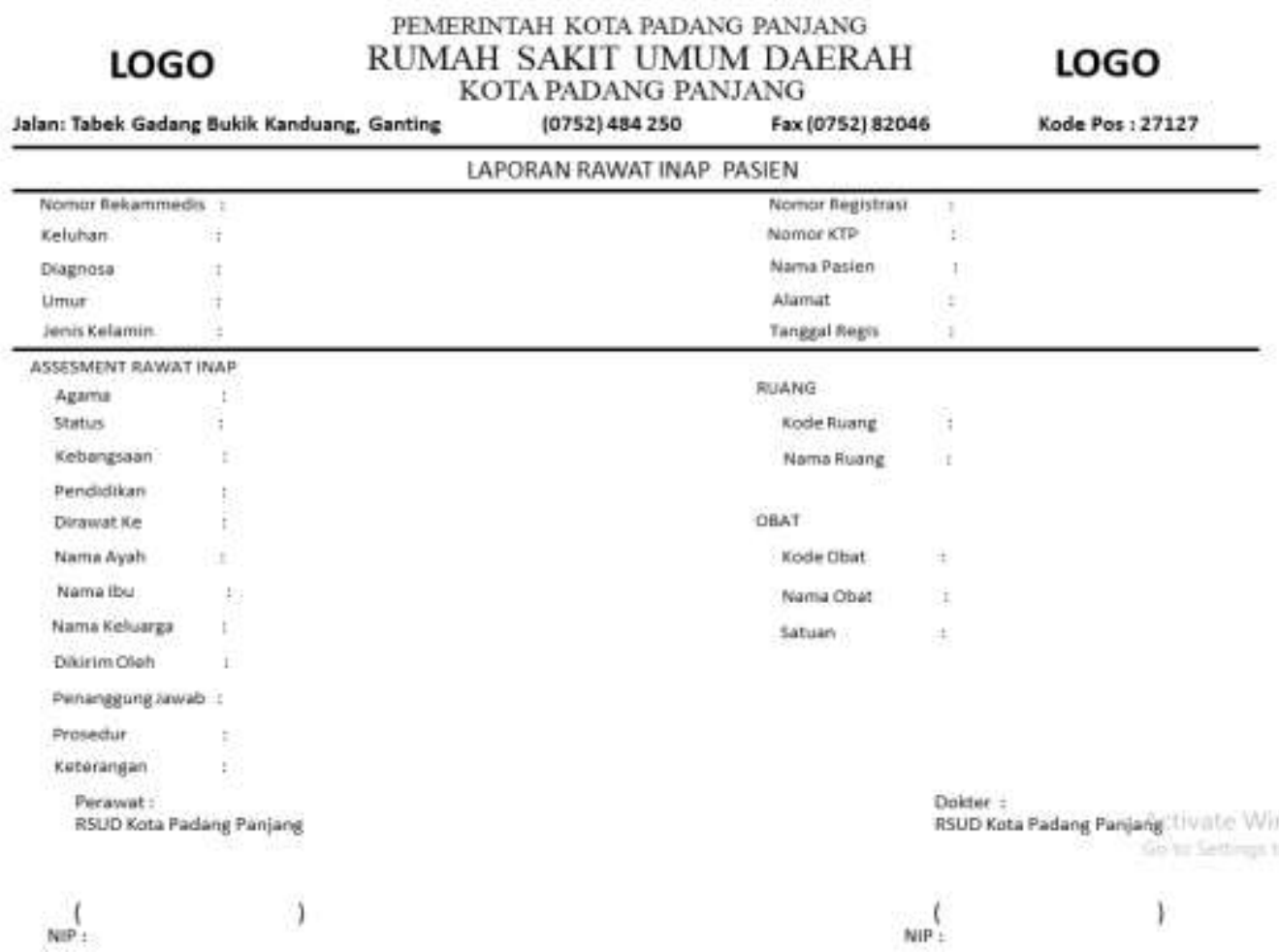

Gambar 5.13 Tampilan Sub Menu Laporan Data Rawat Inap Pasien

\section{Sub Menu Laporan Rawat Jalan pada Admin}


Sub menu laporan data rawat jalan pasien merupakan sub menu yang digunakan untuk mengelola dan mencetak laporan data rawat jalan pasien seperti Gambar 5.14

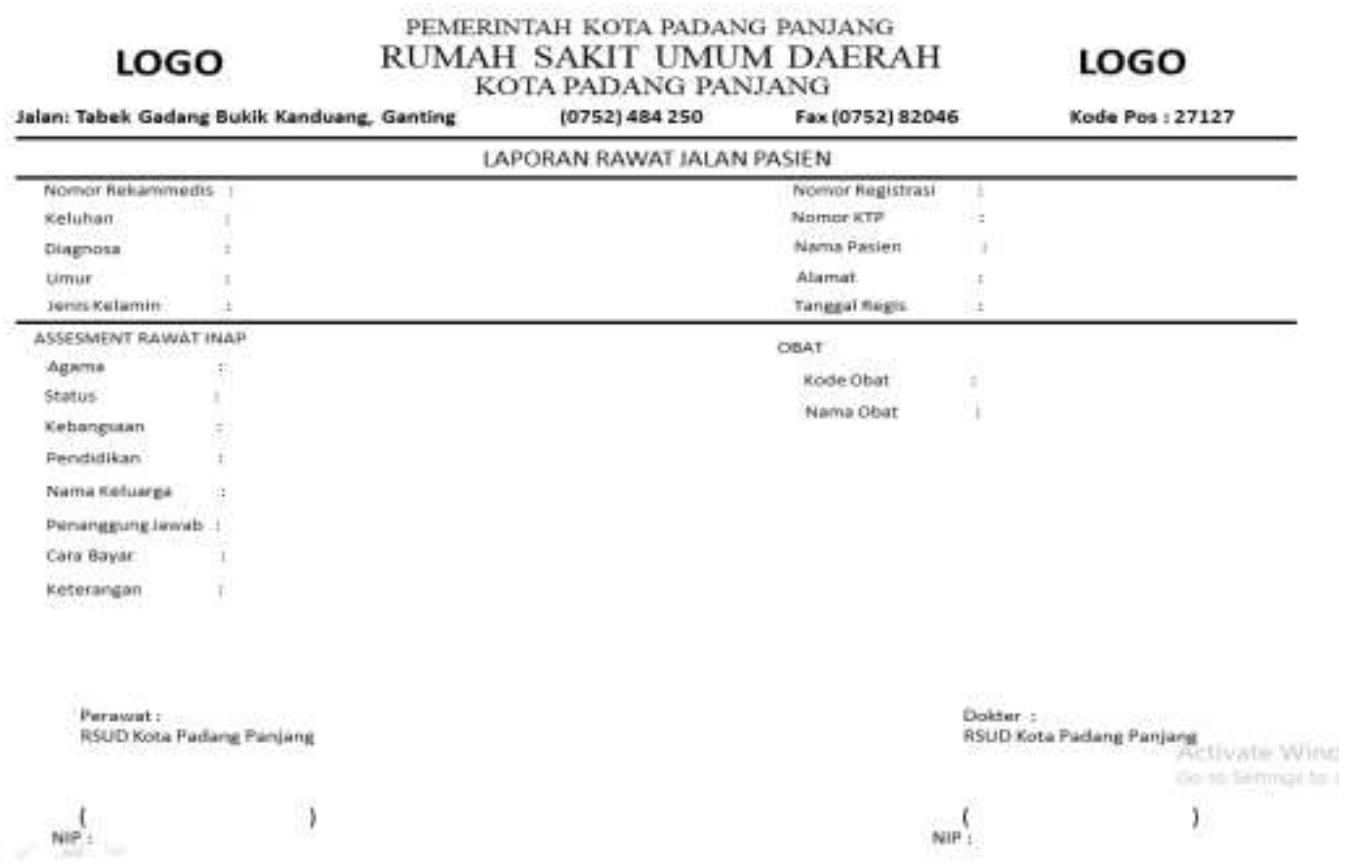

Gambar 5.14 Tampilan Sub Menu Laporan Data Rawat Jalan Pasien

\section{Sub Menu Kelola Data Rekammedis pada Perawat}

Sub menu data rekammedis merupakan sub menu yang digunakan untuk mengelola data rekammedis pasien seperti Gambar 5.15

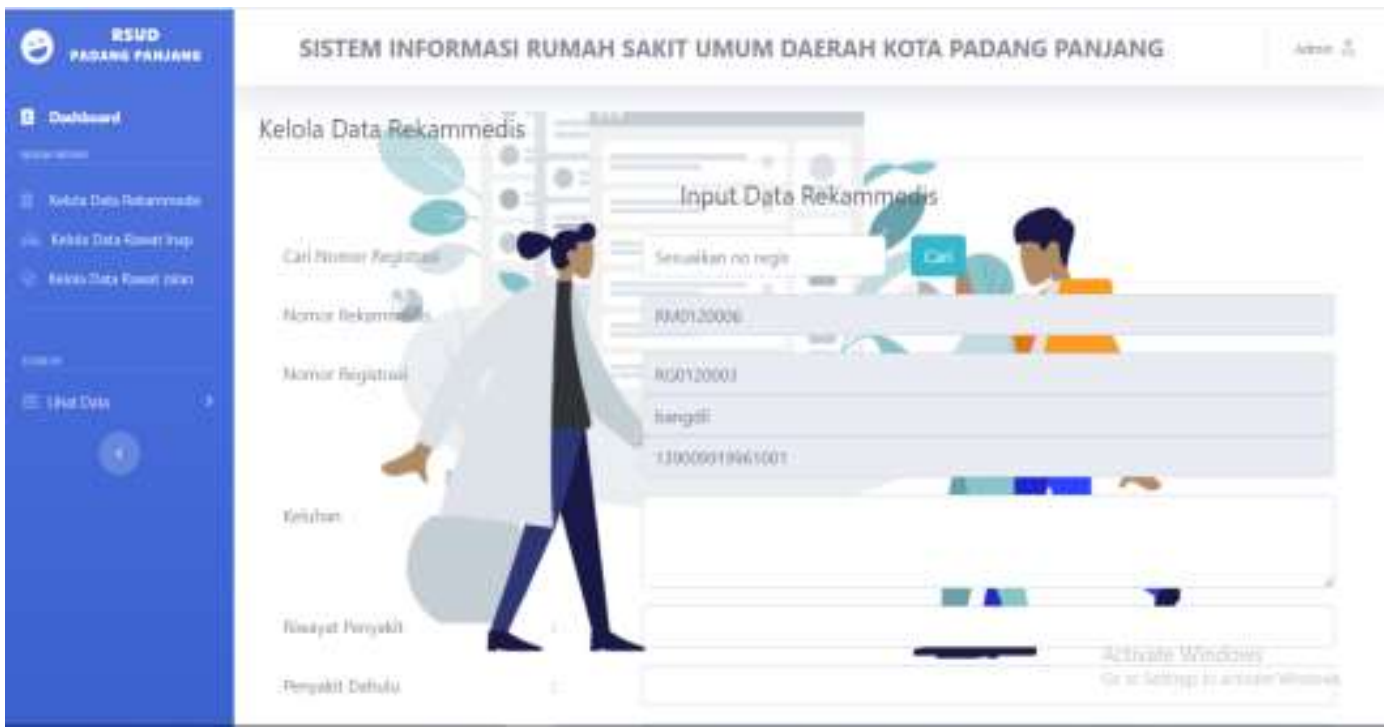

Gambar 5.15 Tampilan Sub Menu Kelola Data Rekammedis

15. Sub Menu Kelola Data Rawat Inap pada Perawat 
Sub menu kelola data rawat inap merupakan sub menu yang digunakan untuk perawat untuk menginputkan data rawat inap, seperti Gambar 5.16

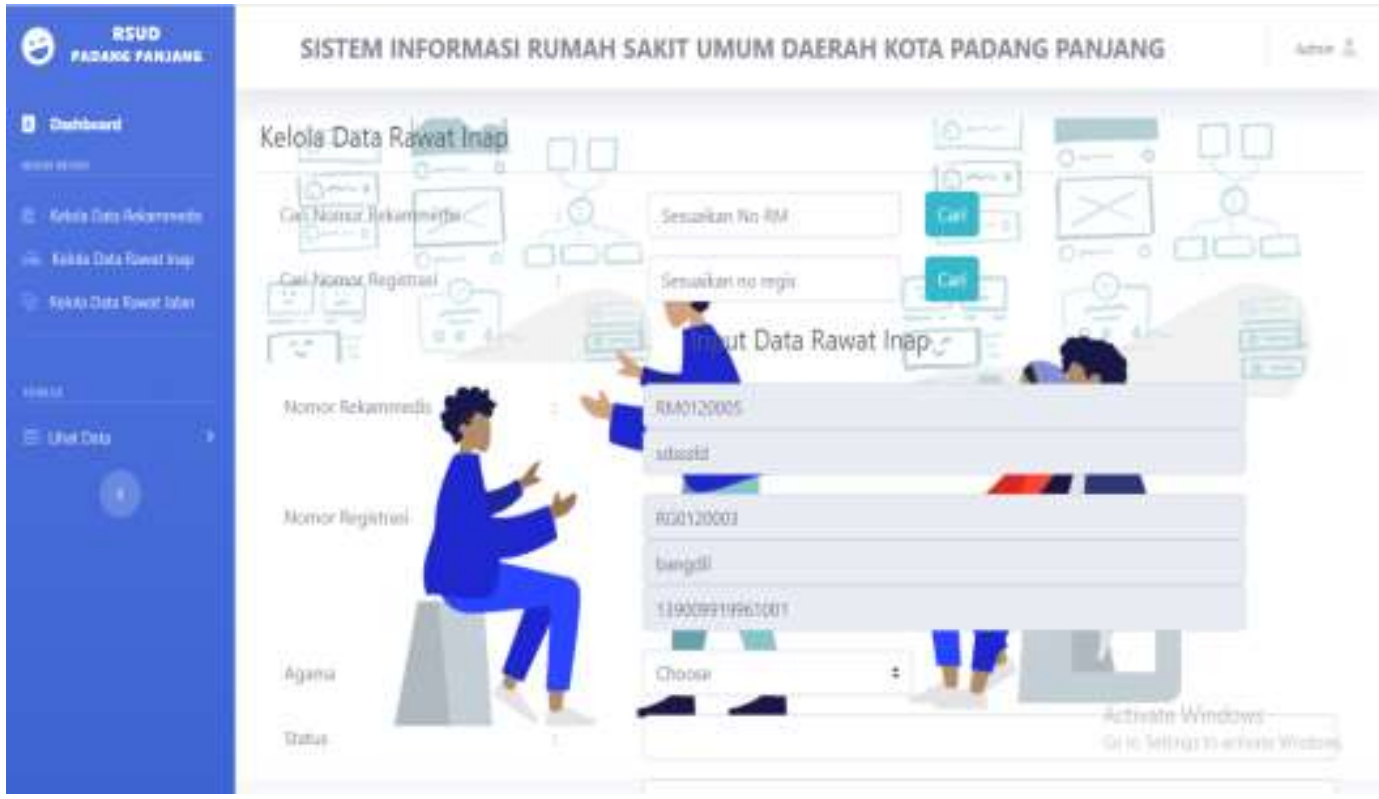

Gambar 5.16 Tampilan Sub Menu Kelola Data Rawat Inap

\section{Sub Menu Kelola Data Rawat Jalan pada Perawat}

Sub menu kelola data rawat jalan merupakan sub menu yang digunakan untuk perawat untuk menginputkan data rawat jalan, seperti Gambar 5.17.

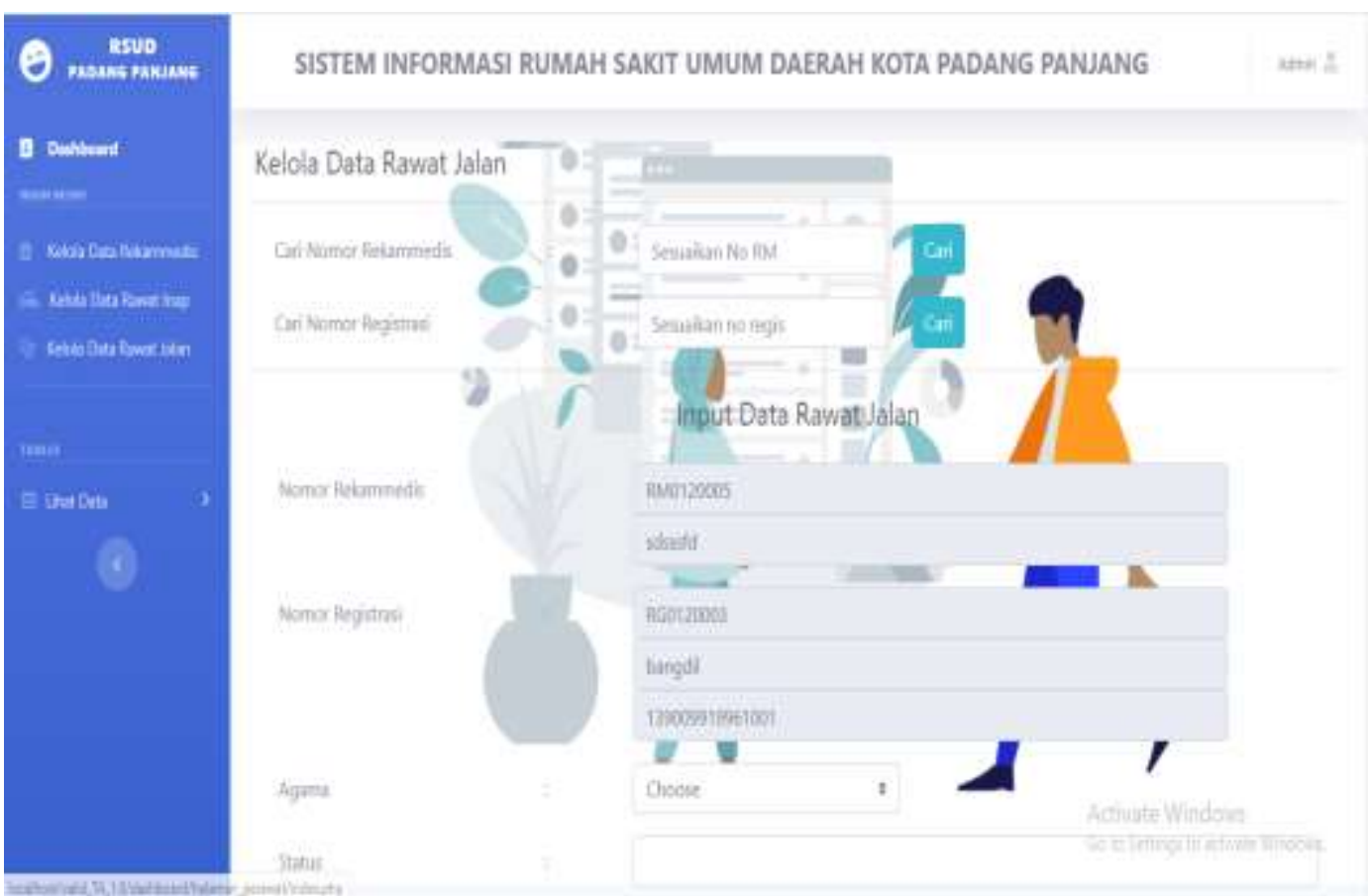

Gambar 4.17 Tampilan Sub Menu Kelola Data Rawat Jalan

17. Sub Menu Lihat Data Rekammedis pada Perawat 
Sub menu lihat data rekammedis merupakan sub menu yang digunakan untuk perawat untuk melihat data hasil entry ke sistem, seperti Gambar 5.18.

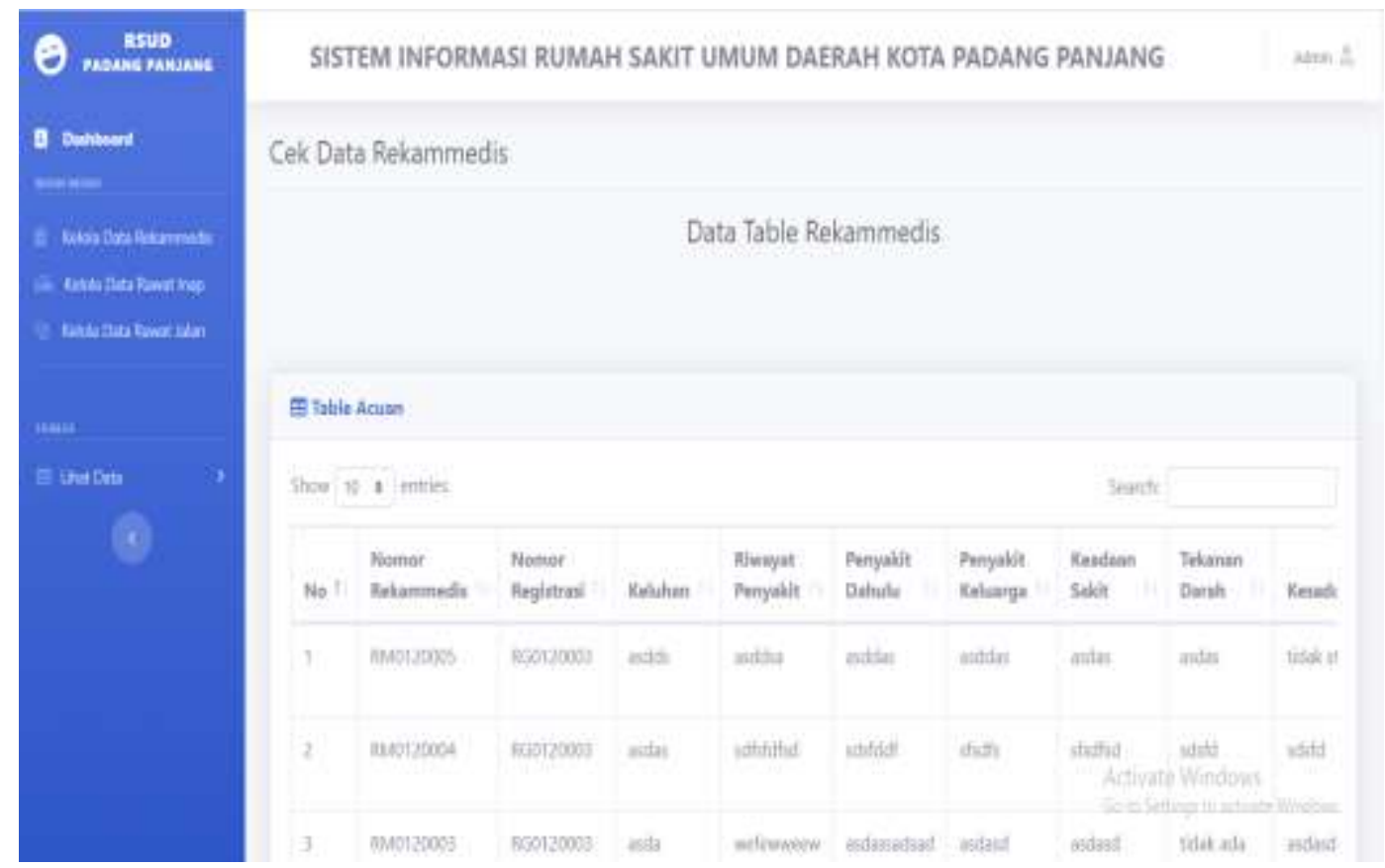

Gambar 5.18 Tampilan Sub Menu Lihat Data Rekammedis pada Perawat

\section{Sub Menu Lihat Data Rawat Inap pada Perawat}

Sub menu lihat data rawat inap merupakan sub menu yang digunakan untuk perawat untuk melihat data hasil entry ke sistem, seperti Gambar 5.19.

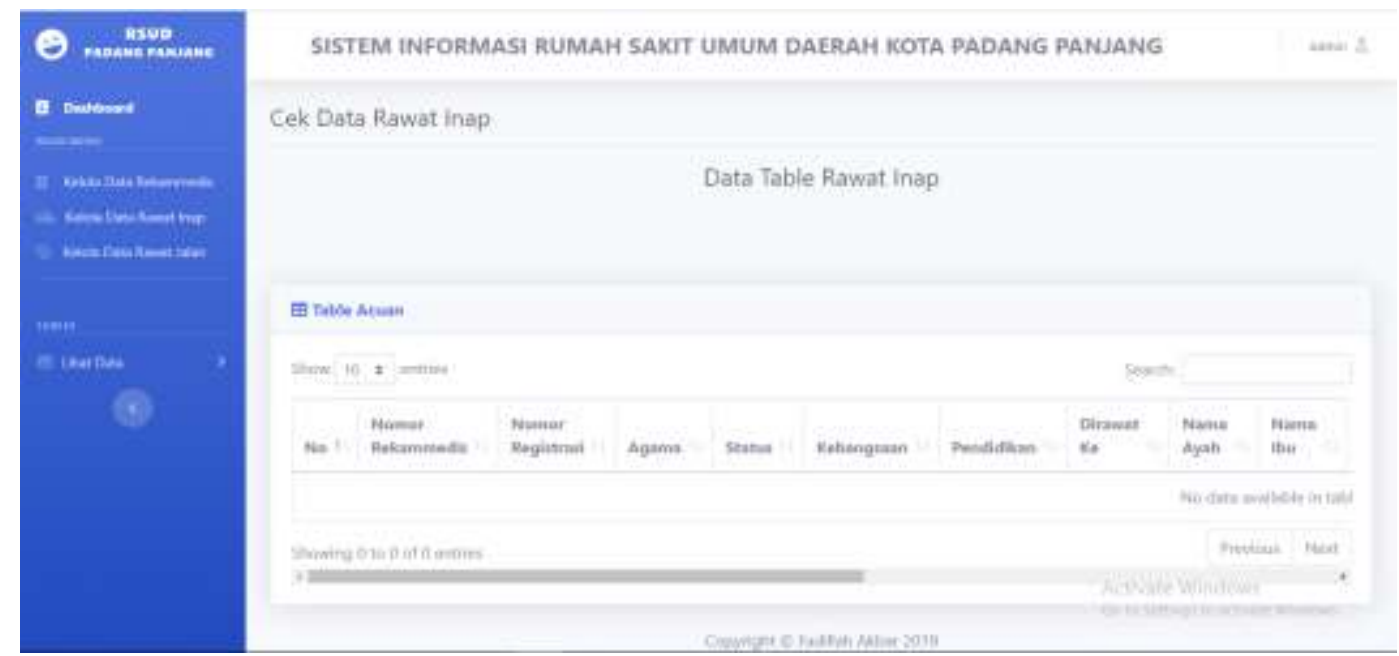

Gambar 5.19 Tampilan Sub Menu Lihat Data Rawat Inap pada Perawat

\section{Sub Menu Lihat Data Rawat Jalan pada Perawat}

Sub menu lihat data rawat jalan merupakan sub menu yang digunakan untuk perawat untuk melihat data hasil entry ke sistem, seperti Gambar 5.20. 


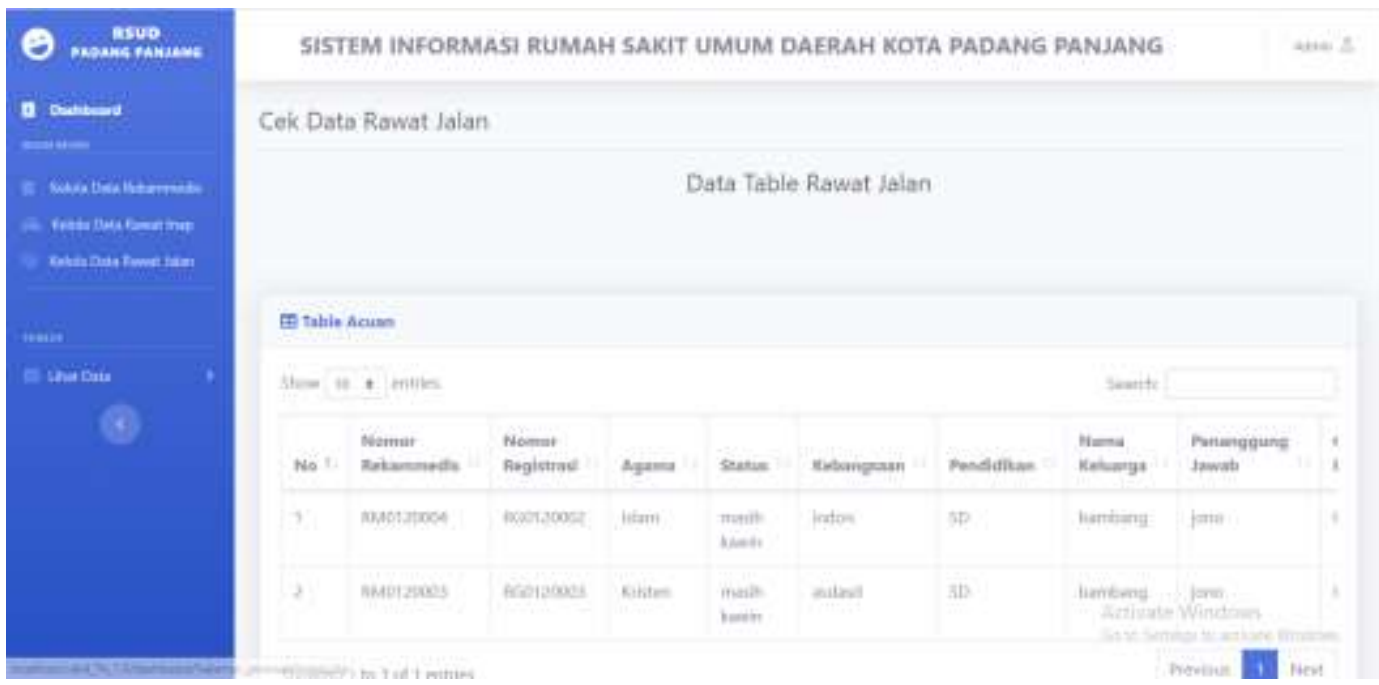

Gambar 5.20 Tampilan Sub Menu Lihat Data Rawat Jalan pada Perawat

\section{Sub Menu Lihat Data Pasien pada Direktur}

Sub menu lihat data pasien merupakan sub menu yang digunakan untuk direktur untuk melihat data hasil input ke sistem, seperti Gambar 5.21.

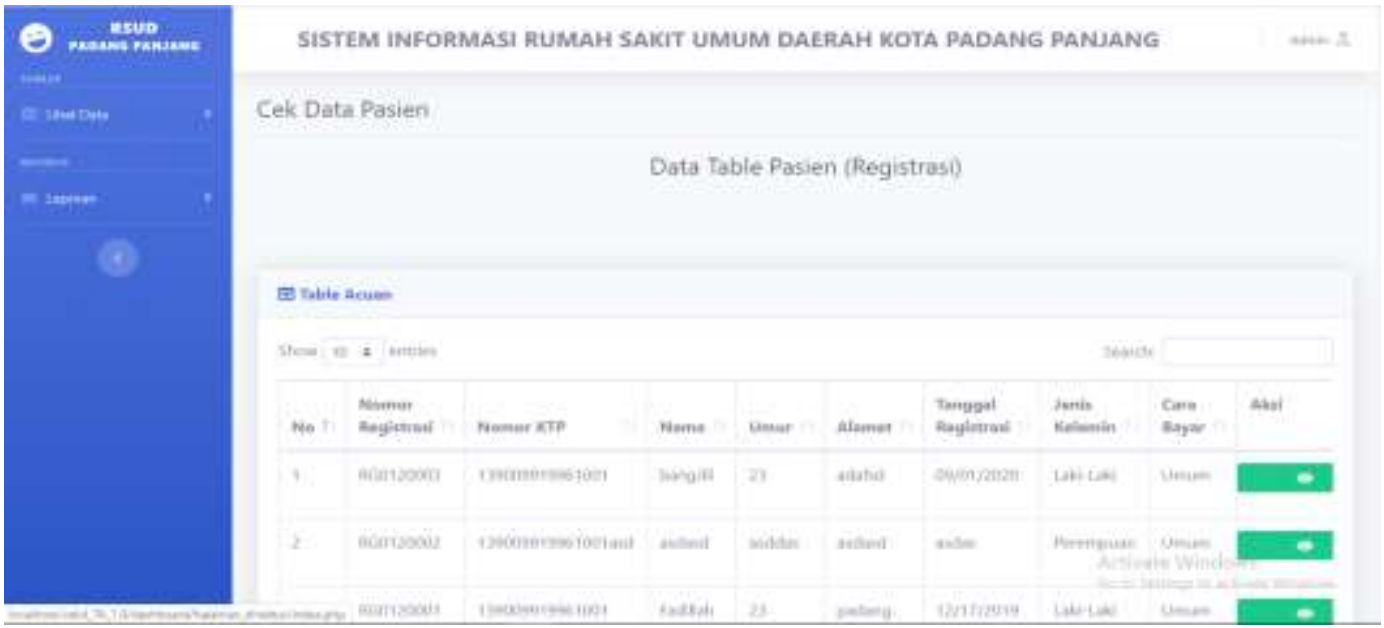

Gambar 5.21 Tampilan Sub Menu Lihat Data Pasien pada Direktur

21. Sub Menu Lihat Data Rekammedis pada Direktur

Sub menu lihat data rekammedis merupakan sub menu yang digunakan untuk direktur untuk melihat data hasil input ke sistem, seperti Gambar 5.22. 


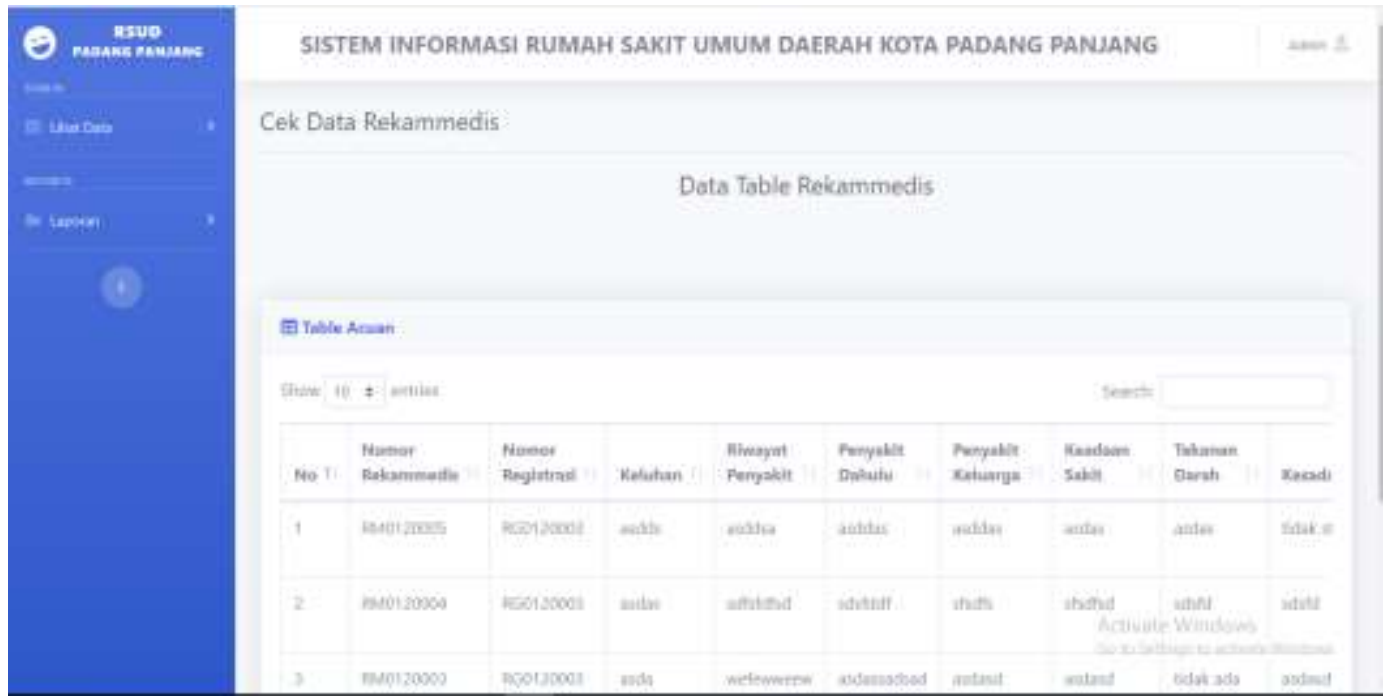

Gambar 5.22 Tampilan Sub Menu Lihat Data Rekammedis pada Direktur

\section{Sub Menu Lihat Data Rawat Inap pada Direktur}

Sub menu lihat data rawat inap merupakan sub menu yang digunakan untuk direktur untuk melihat data hasil input ke sistem, seperti Gambar 5.23.

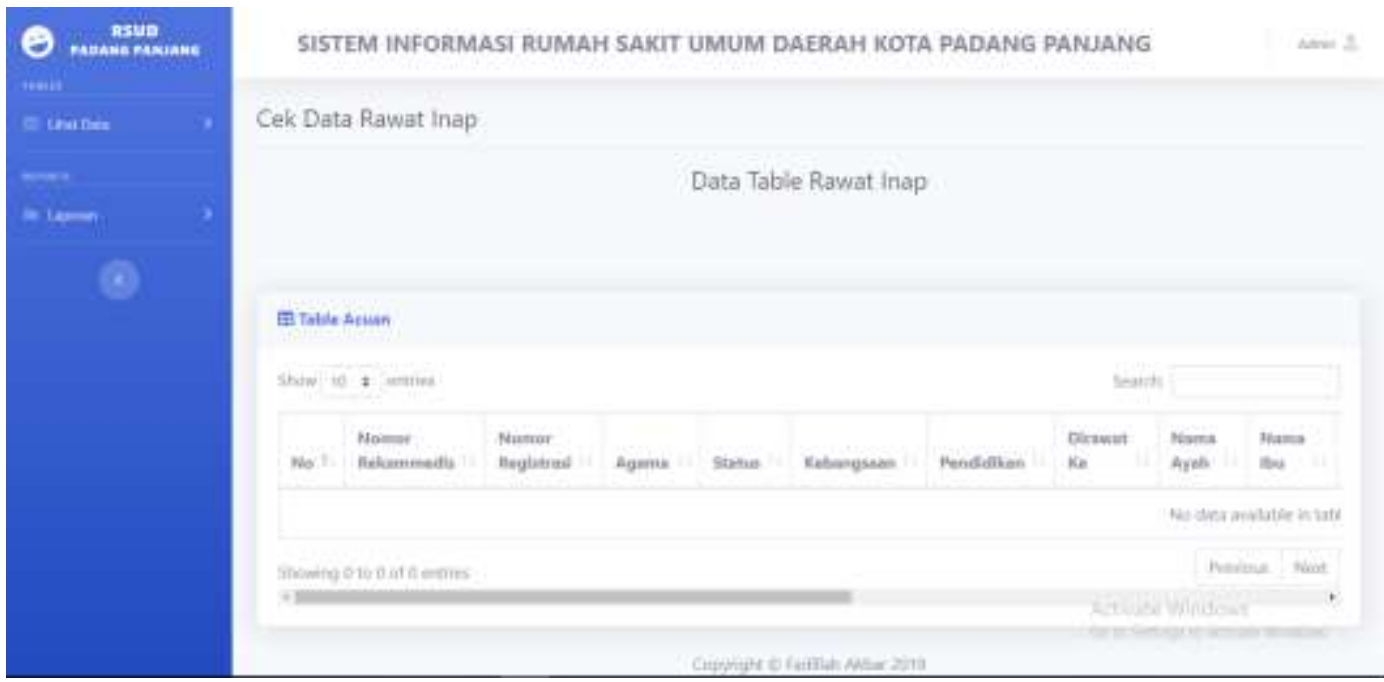

Gambar 5.23 Tampilan Sub Menu Lihat Data Rawat Inap pada Direktur

\section{Sub Menu Lihat Data Rawat Jalan pada Direktur}

Sub menu lihat data rawat jalan merupakan sub menu yang digunakan untuk direktur untuk melihat data hasil input ke sistem, seperti Gambar 5.24. 


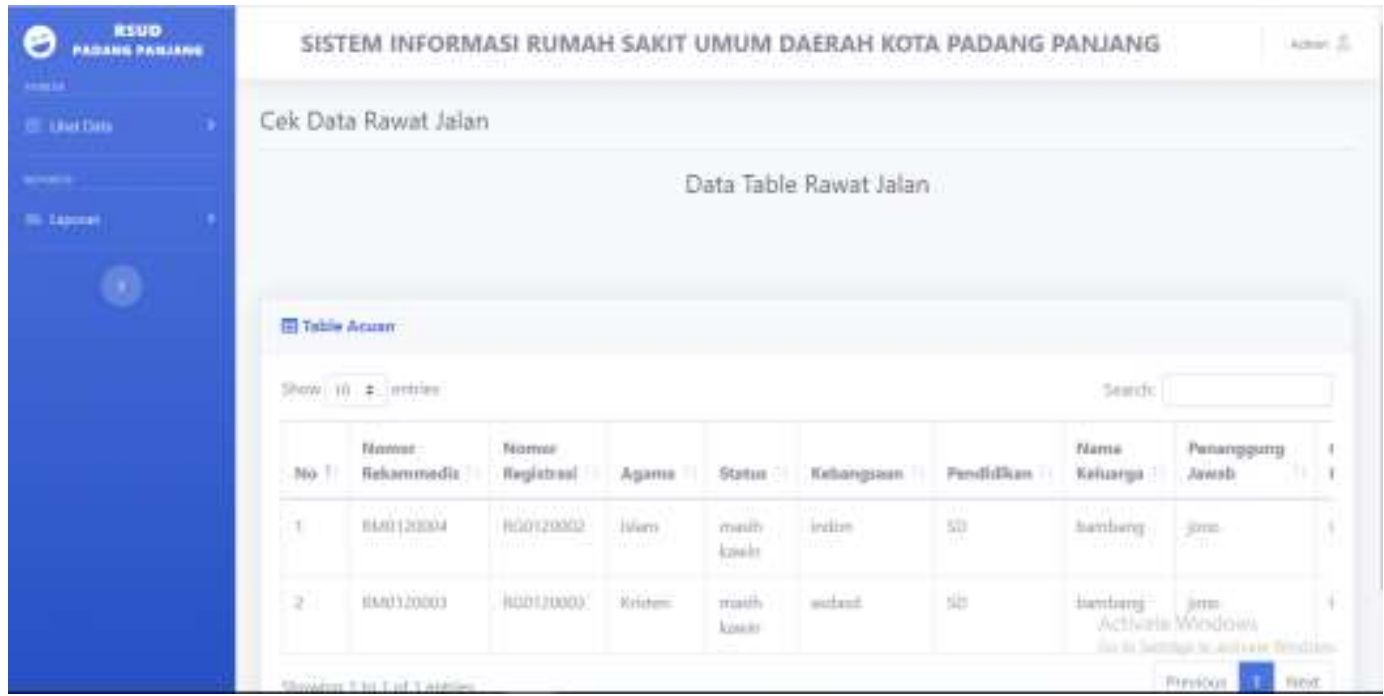

Gambar 5.24 Tampilan Sub Menu Lihat Data Rawat Jalan pada Direktur

\section{Sub Menu Laporan Rekammedis pada Direktur}

Sub menu laporan rekammedis merupakan sub menu yang digunakan untuk direktur mencetak laporan rekammedis, seperti Gambar 5.25.

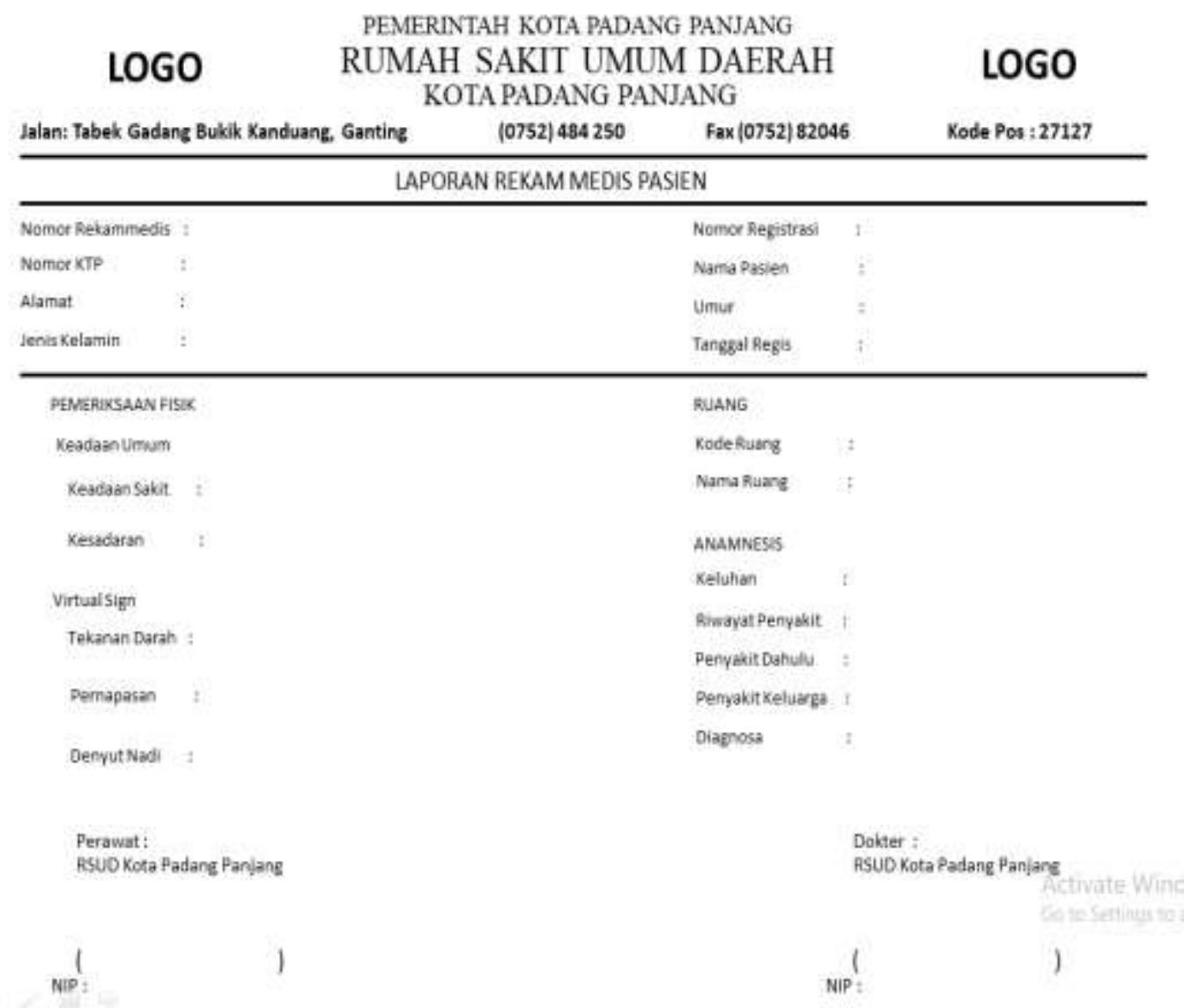

Gambar 5.25 Tampilan Sub Menu Laporan Rekammedis pada Direktur

25. Sub Menu Laporan Rawat Inap pada Direktur 
Copyright@2020 LPPM UPI YPTK

Sub menu laporan rawat inap merupakan sub menu yang digunakan untuk direktur mencetak laporan rawat inap, seperti Gambar 5.26.

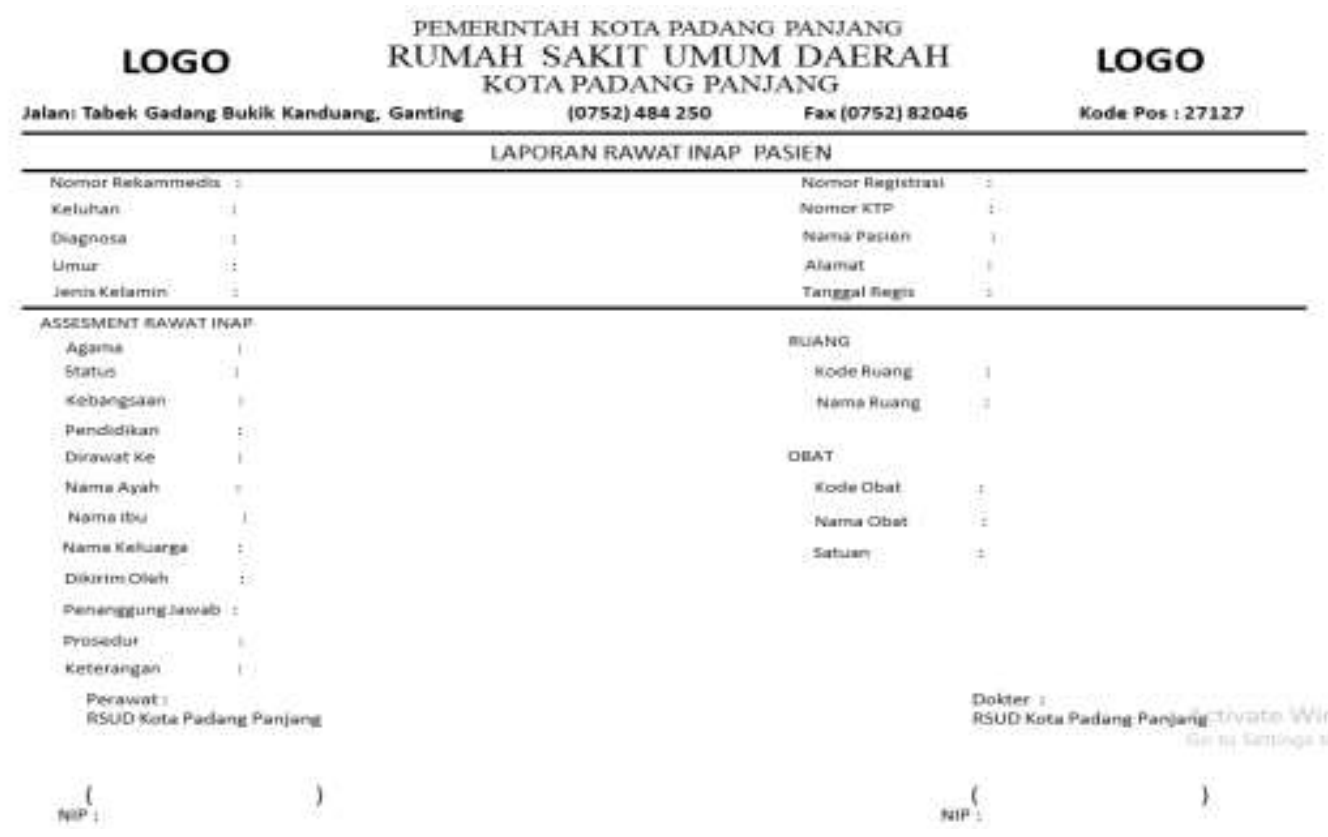

Gambar 5.26 Tampilan Sub Menu Laporan Rawat Inap pada Direktur

\section{Sub Menu Laporan Rawat Jalan pada Direktur}

Sub menu laporan rawat jalan merupakan sub menu yang digunakan untuk direktur mencetak laporan rawat jalan, seperti Gambar 5.27.

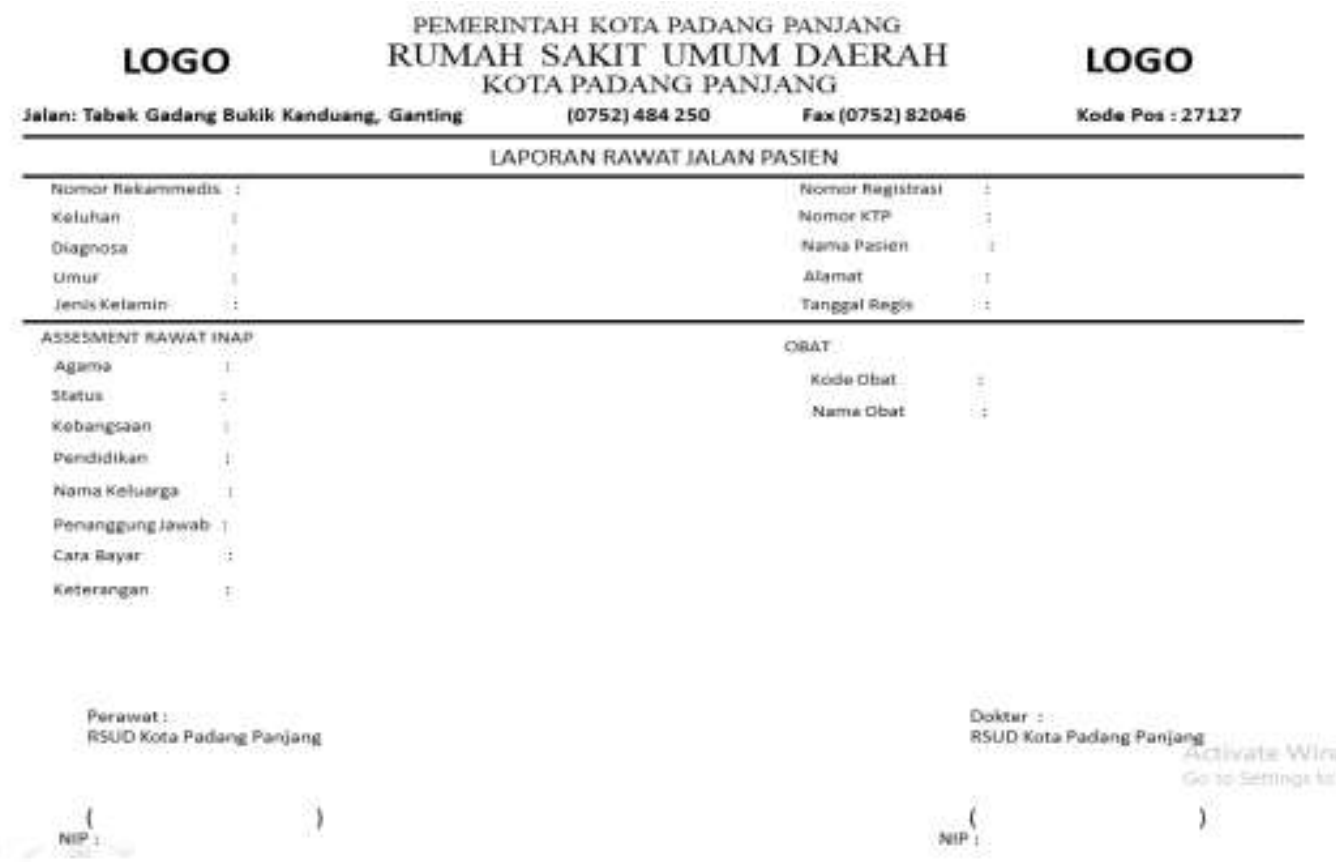

Gambar 5.27 Tampilan Sub Menu Laporan Rawat Jalan pada Direktur 


\section{Kesimpulan}

Berdasarkan hasil penelitian dan pembahasan yang telah diuraikan sebelumnya maka dapat ditarik kesimpulan sebagai berikut:

a. Dengan adanya Sistem Informasi Rumah Sakit Umum Daerah Kota Padang Panjang diharapkan pengolahan data rekammedis, data rawat inap, dan data jalan pada RSUD Kota Padang Panjang lebih mudah dan efisien.

b. Dengan adanya sistem informasi dalam pengolahan data rekammedis, diharapkan dapat meningkatkan efektivitas kerja terutama pada proses rekammedis pasien, rawat jalan pasien, rawat inap, registrasi pasien, obat, ruang dan pembuatan laporan, sehingga dapat mempersingkat waktu pengerjaan.

c. Selain itu dengan aplikasi ini bisa mendapatkan data yang diperlukan dengan terinci dari kegiatan yang dilakukan oleh RSUD Kota Padang Panjang tanpa harus membuka dokumen-dokumen pengolahan data yang telah diarsip karena dapat langsung mengaksesnya setiap saat.

\section{Referensi}

Anastasia Lipursari. 2013. Peran Sistem Informasi Manajemen (SIM) Dalam Pengambilan Keputusan. Jurnal STIE Semarang. 5(1): 27-28.

Alhamidi. 2016. Perancangan dan Implementasi Sistem Penunjang Keputusan Untuk Mendukung Proses Penyeleksian Siswa Baru Pada SMAN 1 Nan Sabaris. Jurnal TEKNOIF. 4(2): 83.

Tomi Loveri. 2018. Sistem Informasi Aplikasi Pengelolaan Transaksi Keuangan dan Pendapatan Konsumen pada CV.PUPLAS. Jurnal Sains dan Informatika. 4(12): 139-145.

Asep Muhidin. 2017. Perancangan Sistem Informasi Produk Hasil Repair pada PT. JVC KENWOOD ELEKTRONIKA INDONESIA. Jurnal Teknologi Pelita Bangsa - SIGMA. 6(2): 150.

Radius Prawiro, S.kom, M.kom. 2017. Mengaplikasikan Bahasa Pemrograman PHP dan DATABASE MySql dengan Menggunakan UML dalam Perancangan Sistem Pengolahan Data Spare Part Motor pada PT. Thamrin Brothers Mukumuko. Jurnal KomTekInfo. 4(2): 187.

Fitri Ayu, Nia Permatasari. 2018. Perancangan Sistem Informasi Pengolahan Data Praktek Kerja Lapangan (PKL) Pada Devisi Humas PT. Pegadaian. Jurnal Intra-Tech. 2(2): 14-15.

Sutabri, Tata. 2012. Konsep Sistem Informasi. Jakarta: Penerbit ANDI

Mohamad Topan, dkk. 2015. Perancangan Sistem Informasi Manajemen Rumah Sakit Berbasis Web Studi Kasus: Rumah Sakit TNI AU Lanud Sam Ratulangi. E-jurnal Teknik Informatika. 6(1). 
Copyright@2020 LPPM UPI YPTK

Vindra Yudha Hendrawan, dkk. 2014. Sistem Informasi Rekammedis Rawat Jalan dan Pemeriksaan Penunjang Diagnosa Berbasis Website (Studi Kasus: Rumah Sakit Khusus Bedah Klinik Sinduadi, Mlati, Sleman, Yogyakarta. Jurnal Teknologi Informasi. 4(27): 55.

Tiara Handayani, dkk. 2016. Perancangan Sistem Informasi Rekammedis Berbasis Web (Studi Kasus di Klinik Bersalin Sriati Kota Sungai Penuh Jambi. Jurnal Teknologi Informasi dan Komputer. 2(2).

S. Rosa, Shalahuddin, M. 2018. Rekayasa Perangkat Lunak. Bandung. Informatika Bandung.

Drs. Hermansyah Sembiring, M.Kom, dkk. 2012. Sistem Informasi Jumlah Angkatan Kerja Menggunakan Visual Basic Pada Badan Pusat Statistik (BPS) Kabupaten Langkat. Jurnal Kaputama. 5(2)

Mara Destiningrum, dkk. 2017. Sistem Informasi Penjadwalan Dokter Berbasis Web Dengan Menggunakan Framework Codeigniter (Studi Kasus: Rumah Sakit Yakum Medical Centre). 11(2).

Gusman, A. P., Mardison, M., \& Azmi, W. J. (2019). ANALISA SISTEM INFORMASI AKUNTANSI UNTUK TRANSAKSI PENJUALAN LABA RUGI DENGAN MENGGUNAKAN VB. NET. MAJALAH ILMIAH, 26(2), 55-64. 